\title{
Perennial ponds are not an important source of water or dissolved organic matter to groundwaters with high arsenic concentrations in West Bengal, India
}

\author{
Saugata Datta, ${ }^{1}$ Andrew W. Neal, ${ }^{1}$ T. Jade Mohajerin, ${ }^{2}$ Troy Ocheltree, ${ }^{3}$ \\ Brad E. Rosenheim, ${ }^{2}$ Christopher D. White, ${ }^{4}$ and Karen H. Johannesson ${ }^{2}$ \\ Received 12 August 2011; revised 20 September 2011; accepted 24 September 2011; published 26 October 2011.
}

[1] Arsenic (As) concentrations and stable hydrogen $\left(\delta^{2} \mathrm{H}\right)$ and oxygen $\left(\delta^{18} \mathrm{O}\right)$ isotope ratios of surface and groundwaters from a representative site in West Bengal, India, are reported. Shallow groundwaters $(\leq 35 \mathrm{~m})$ from the study site have among the highest As concentrations measured in the entire Bengal Basin, reaching values in excess of $4600 \mu \mathrm{g} \mathrm{kg}^{-1}$. Stable isotope ratios of waters from constructed, perennial ponds indicate the ponds are chiefly recharged during the summer monsoon, and subsequently undergo extensive evaporation during the dry (winter) season. In contrast, groundwaters with high As concentrations plot along the local meteoric water line (LMWL) near where the annual, volume-weighted mean precipitation values for $\delta^{2} \mathrm{H}$ and $\delta^{18} \mathrm{O}$ would plot. The stable isotope data demonstrate that groundwaters are directly recharged by local precipitation without significant evaporation, and thus are not recharged by, nor mixed with, the pond waters. Furthermore, reactive transport modeling indicates that dissolved organic matter (DOM) derived from pond waters does not fuel microbial respiration and As mobilization at depth in the underlying aquifer because travel times for pond-derived DOM exceed groundwater ages by thousands of years. Instead, organic matter within the aquifer sediments must drive dissimilatory iron reduction and As release to groundwaters. Citation: Datta, S., A. W. Neal, T. J. Mohajerin, T. Ocheltree, B. E. Rosenheim, C. D. White, and K. H. Johannesson (2011), Perennial ponds are not an important source of water or dissolved organic matter to groundwaters with high arsenic concentrations in West Bengal, India, Geophys. Res. Lett., 38, L20404, doi:10.1029/2011GL049301.

\section{Introduction}

[2] Mass poisoning of human populations from drinking water sources containing high arsenic (As) concentrations have been reported globally [Ravenscroft et al., 2009]. However, none has sickened more people than the current As crisis afflicting the Bengal Basin of South Asia, which has been referred to as the greatest natural mass poisoning in human

\footnotetext{
${ }^{1}$ Department of Geology, Kansas State University, Manhattan, Kansas, USA.

${ }^{2}$ Department of Earth and Environmental Sciences, Tulane University, New Orleans, Louisiana, USA. USA.

${ }^{3}$ Division of Biology, Kansas State University, Manhattan, Kansas,

${ }^{4}$ Department of Petroleum Engineering, Louisiana State University, Baton Rouge, Louisiana, USA.

Copyright 2011 by the American Geophysical Union. 0094-8276/11/2011GL049301
}

history [Smith et al., 2000]. Roughly 60 million people in the Bengal Basin (Bangladesh and West Bengal, India) are currently drinking water with As concentrations in excess of $50 \mu \mathrm{g} \mathrm{kg}^{-1}$ (the legal limit for As in drinking waters in India and Bangladesh). Both the World Health Organization and U.S. Environmental Protection Agency have set $10 \mu \mathrm{g} \mathrm{kg}^{-1}$ as the safe drinking water limit for As in water [Yu et al., 2003].

[3] The source of As to the Bengal Basin is thought to be geogenic, possibly originating in As-rich lithologies in the headwater regions of the Ganges river system as the Ganges is the primary source of sediments to West Bengal and neighboring western Bangladesh [Ravenscroft et al., 2009]. Although the mechanisms of As mobilization from Bengal Basin sediments into local groundwaters are complicated and incompletely understood, the current consensus is that microbially mediated reductive dissolution of secondary iron oxide/oxyhydroxides coupled to organic matter oxidation, and the subsequent release of associated As (adsorbed or coprecipitated) into the groundwater is the chief process leading to As mobilization [Nickson et al., 2000; Harvey et al., 2002; Zheng et al., 2004]. Nonetheless, specific questions remain regarding the As-affected groundwaters of the Bengal Basin, including the source of dissolved organic matter (DOM) driving microbial respiration and whether the increase in irrigation pumping since the 1970's has exacerbated As mobilization [Harvey et al., 2002, 2006; van Geen et al., 2003; McArthur et al., 2004; Neumann et al., 2010]. A number of recent investigations suggest that perennial ponds, chiefly constructed by local populations in the last 50 years and used for bathing, washing, and aquiculture, represent a major source of recharge water and DOM to the As-affected, shallow groundwaters, owing in part to increased flushing of the shallow aquifers that results from irrigation pumping [e.g., Harvey et al., 2006; Neumann et al., 2010]. Others argue that aquifer sediments contain sufficient organic matter to catalyze Fe reduction and that these ponds contribute little recharge water and DOM to the underlying groundwaters [McArthur et al., 2004; Sengupta et al., 2008]. Here, we use the conservative stable hydrogen and oxygen isotopes of the water molecule and reactive transport modeling to demonstrate that water from perennial ponds is an insignificant source of recharge and DOM to West Bengal groundwaters. Instead, the organic matter that drives microbial respiration and subsequent As mobilization must occur locally within the aquifers.

\section{Site Description}

[4] The study site is along the river Bhagirathi, a distributary of the Ganges that flows south to the Bay of 


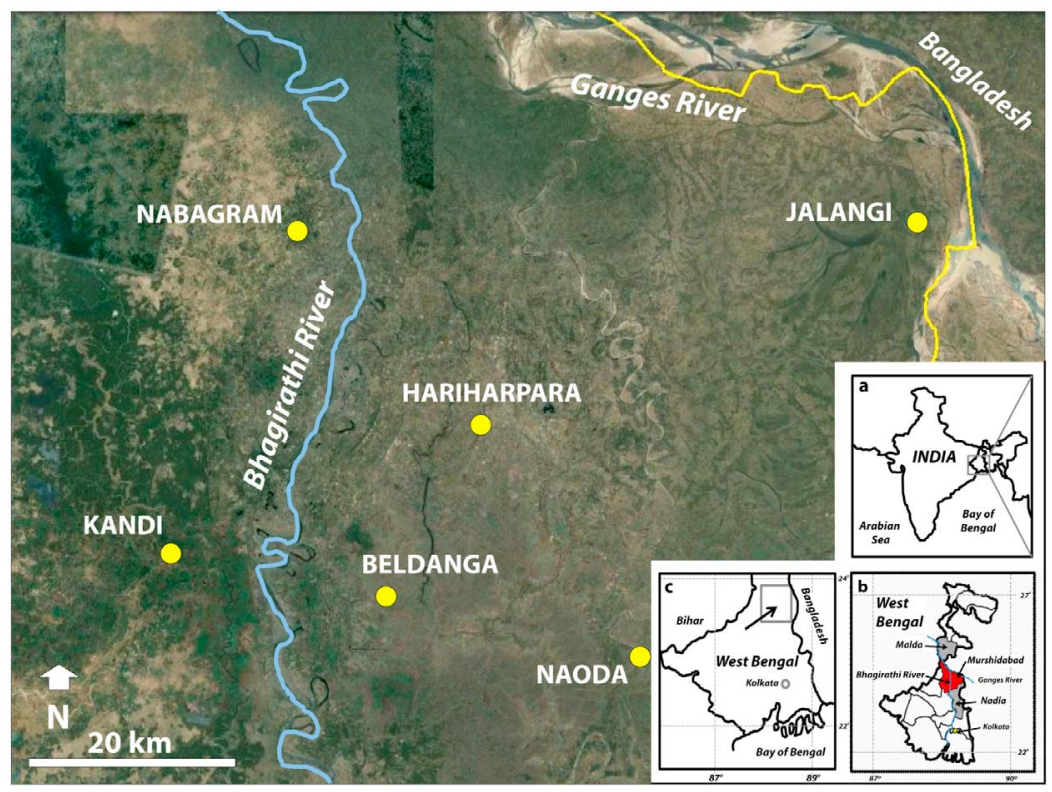

Figure 1. Map showing the study site in the Murshidabad district of West Bengal, India, with respect to the rivers Bhagirathi and Ganges. Inset maps show (a) location of West Bengal within India, (b) the location of the Murshidabad district in West Bengal, and (c) the location of our study site in the Murshidabad district. Details of each of the sampling locations are provided in Figure S1 of the auxiliary material.

Bengal through the Murshidabad district of West Bengal, India (Figure 1). The region is characterized by older (Pleistocene) river terrace sediments to the west of the river Bhagirathi and younger (Holocene) paleo-channels, paleointerfluves and relict oxbow lakes sediments east of the river [Neal et al., 2010]. Two blocks on the west bank of the river Bhagirathi (i.e., Nabagram and Kandi) and four blocks east of the river (Beldanga, Hariharpara, Naoda, and Jalangi) were investigated (Figure 1). Surface sediments at each site are silty clays that exceed $9 \mathrm{~m}$ thick except at Nabagram, where the thickness of the surface confining layer is only 3 $\mathrm{m}$ [Neal et al., 2010]. Fine to medium sands underlie the surficial aquitard at each site [Neal et al., 2010].

\section{Methods}

[5] Groundwater samples were collected at well-heads from shallow tubewells and irrigation wells within the six targeted blocks of Murshidabad during two consecutive dry seasons (2009 and 2010; Figure 1 and auxiliary material). ${ }^{1}$ The majority of groundwaters (both the tubewells and irrigation wells) were collected from depths of $\sim 30 \mathrm{~m}$ (Table S1). Surface waters were also collected from a number of shallow ponds (mean depth $\sim 3 \mathrm{~m}$ ), and the rivers Bhagirathi and Ganges during both sampling campaigns. Water samples were analyzed for stable oxygen and hydrogen isotope ratios using cavity ring-down spectrometry (Picarro L2120- $i$; see auxiliary material), and for dissolved As concentrations using high-resolution (magnetic sector) inductively coupled plasma mass spectrometry (Finnigan MAT Element II) as described by Haque et al. [2008]. A one-dimensional advection/dispersion transport model linked to the diffuse double layer surface complexation model was employed to

\footnotetext{
${ }^{1}$ Auxiliary materials are available in the HTML. doi:10.1029/ 2011 GL049301.
}

assess travel times of pond-derived DOM into the underlying aquifer (see auxiliary material). Surface complexation modeling is necessary to simulate the non-conservative transport of DOM in aquifers [Sengupta et al., 2008]. The model assumes a uniform sand layer of $60 \mathrm{~m}$ with a porosity of $30 \%$, and a concentration of DOM in the pond water of $1.5 \mathrm{mmol} \mathrm{kg}^{-1}$ [Neumann et al., 2010].

\section{Results and Discussion}

[6] Arsenic concentrations in surface and groundwaters from the Murshidabad district range from below detection $\left(<0.01 \mu \mathrm{g} \mathrm{kg}^{-1}\right)$ to more than $4600 \mu \mathrm{g} \mathrm{kg}^{-1}$ (Table 1). Arsenite predominates accounting for $54 \%$ to $>98 \%$ of As in solution. Groundwater from east of the river Bhagirathi (Beldanga, Hariharpara, Naoda, and Jalangi blocks) have high, albeit, variable As concentrations, whereas As concentrations of groundwaters collected from west of the Bhagirathi (Nabagram and Kandi blocks) are generally low (Table 1). The difference in groundwater As concentrations on either side of the river Bhagirathi reflects, in part, the difference in aquifer sediments. Specifically, west bank aquifer sediments are oxidized (orange-brown in color) and contain abundant Fe(III) oxide coatings on mineral grains, whereas aquifer sediments east of the river are reduced, gray in color, and contain lower amounts of Fe(III) oxides [Neal et al., 2010]. It is well known that As strongly sorbs onto Fe (III) oxide surfaces [Dixit and Hering, 2003; McArthur et al., 2010]. The broad spatial differences in As concentration with respect to the river Bhagirathi are also reflected in irrigation water applied to rice fields on either side of the river, with irrigation waters from the west bank producing low As concentrations ( $3 \mu \mathrm{g} \mathrm{kg}^{-1}$, Nabagram), and those from east of the river exhibiting high As concentrations $\left(579 \mu \mathrm{g} \mathrm{kg}^{-1}\right.$, Jalangi; Table 1). In contrast, surface waters (i.e., ponds and 
Table 1. Arsenic Concentrations $\left(\mu \mathrm{g} \mathrm{kg}^{-1}\right)$ in Murshidabad Surface and Groundwaters

\begin{tabular}{|c|c|c|c|c|c|c|c|c|}
\hline & Beldanga & Hariharpara & Jalangi & Nabagram & Kandi & Irrigation $^{\mathrm{a}}$ & Ponds & Rivers \\
\hline Minimum & 3 & 43 & 37 & 0.94 & 10 & 3 & 2 & $\overline{\mathrm{BD}^{\mathrm{b}}}$ \\
\hline Maximum & 4622 & 695 & 649 & 3 & 11 & 579 & 4 & 2 \\
\hline Mean & 1248 & 345 & 283 & 1.99 & 10.5 & 165 & 3 & 3 \\
\hline SD & 1910 & 167 & 307 & 1.01 & 0.7 & 277 & 1 & \\
\hline Median & 76.5 & 343 & 107 & 2 & 10.5 & 38 & 3 & \\
\hline$n$ & 12 & 14 & 5 & 5 & 2 & 4 & 8 & \\
\hline
\end{tabular}

${ }^{\mathrm{a}}$ Only four of the sampled irrigation wells had detectable As concentrations. These were as follows: well irw-jb from the Jalangi block, $579 \mu \mathrm{g}$ kg ${ }^{-1}$; well irw-1na from the Naoda block, $24 \mu \mathrm{g} \mathrm{kg}^{-1}$; well irw-2na from the Naoda block, $52 \mu \mathrm{g} \mathrm{kg}^{-1}$; well iw-2nbk from the Nabagram block, $3 \mu \mathrm{g} \mathrm{kg}$.

${ }^{\mathrm{b}} \mathrm{BD}=$ below detection $\left[>0.01 \mu \mathrm{g} \mathrm{kg}^{-1}\right.$; Haque et al., 2008].

rivers) exhibit low As concentrations that did not exceed $4 \mu \mathrm{g} \mathrm{kg}^{-1}$ during our sampling campaigns (Table 1).

[7] Stable oxygen and hydrogen isotope ratios for summer (monsoon) and winter (dry season) precipitation from West Bengal, India define a local meteoric water line (LMWL; $\delta^{2} \mathrm{H}=7.83 \delta^{18} \mathrm{O}+9.01, \mathrm{r}=0.965$; all fits are computed by the reduced major axis method, because the isotope measurements are assumed to have comparable errors). Groundwaters with high As concentrations from east of the river Bhagirathi all plot on or along the LMWL (Figure 2). Groundwaters from the Kandi block as well as the majority of the sampled irrigation waters also plot on the LMWL, although a number of groundwater samples from Nabagram plot below the LWML along an apparent evaporation line (see below). In contrast, waters from constructed, perennial ponds exhibit a strong evaporation trend from the LMWL that is defined by an evaporation line of $\delta^{2} \mathrm{H}=5.76 \delta^{18} \mathrm{O}-$ 9.34 (Figure 2). The pond evaporation line intersects the LMWL at $\delta^{2} \mathrm{H}=-61.65 \%$ and $\delta^{18} \mathrm{O}=-9.08 \%$, indicating pond waters are recharged during the height of the summer monsoon and subsequently undergo substantial enrichment. The distinctness of pond water, eastern, and Nabagram waters has been verified statistically, confirming the provenance and qualitative differences discussed above (see auxiliary material).

[8] The stable isotope data for Murshidabad waters suggest that waters from perennial ponds are not an important source of recharge to the shallow, As-affected aquifers of Murshidabad. Specifically, because they plot along the LMWL, the majority of the Murshidabad groundwaters, and in particular the high As groundwaters from Beldanga, Hariharpara, and Jalangi, have not been appreciably affected by evaporation. Furthermore, the strong evaporation trend that characterizes the local pond waters is not discernable in these high As groundwaters. Consequently, the high As groundwaters cannot be recharged to a substantial degree by the evaporated pond waters, nor can they be explained by mixing of groundwaters with pond waters. Groundwaters from Murshidabad instead plot on the LMWL between the monsoon and dry season extremes, indicating that these groundwaters are directly recharged by meteoric precipitation. The variation of $\delta^{2} \mathrm{H}$ and $\delta^{18} \mathrm{O}$ values for local precipitation is attenuated in Murshidabad groundwaters from the seasonal extremes as is commonly observed in groundwater systems [e.g., Clark and Fritz, 1997].

[9] Groundwaters from Nabagram, which do not have high As concentrations, plot along an evaporation line of $\delta^{2} \mathrm{H}=5.39 \delta^{18} \mathrm{O}-1.46$ that intersects the LMWL at $\delta^{2} \mathrm{H}=$ $-24.31 \%$ and $\delta^{18} \mathrm{O}=-4.24 \%$, where the majority of Murshidabad groundwaters plot (Figure 2). Hence, Nabagram groundwaters are not mixtures of precipitation and evaporated pond waters, but instead reflect evaporated shallow groundwaters. We note that the surficial confining layer is only $3 \mathrm{~m}$ thick at the Nabagram site. Consequently, the relatively thin surface confining layer may facilitate enrichment of shallow groundwaters during the dry season, which is less likely at the other sites owing to the much thicker surficial clay layers [Neal et al., 2010]. Alternatively, because irrigation waters that exhibit evidence for evaporation are all from west of the river Bhagirathi, Nabagram groundwaters may also include a component of evaporated irrigation water that re-infiltrated back through the thin confining layer and into the underlying aquifer sands.

[10] The one-dimensional, reactive transport model indicates that downward transport of pond-derived DOM to depths in the underlying aquifer where As mobilization is greatest $(\sim 30 \mathrm{~m})$ is unlikely to be significant over time scales consistent with the estimated ages of groundwater at these depths (e.g., 50 years [Klump et al., 2006; Stute et al., 2007;

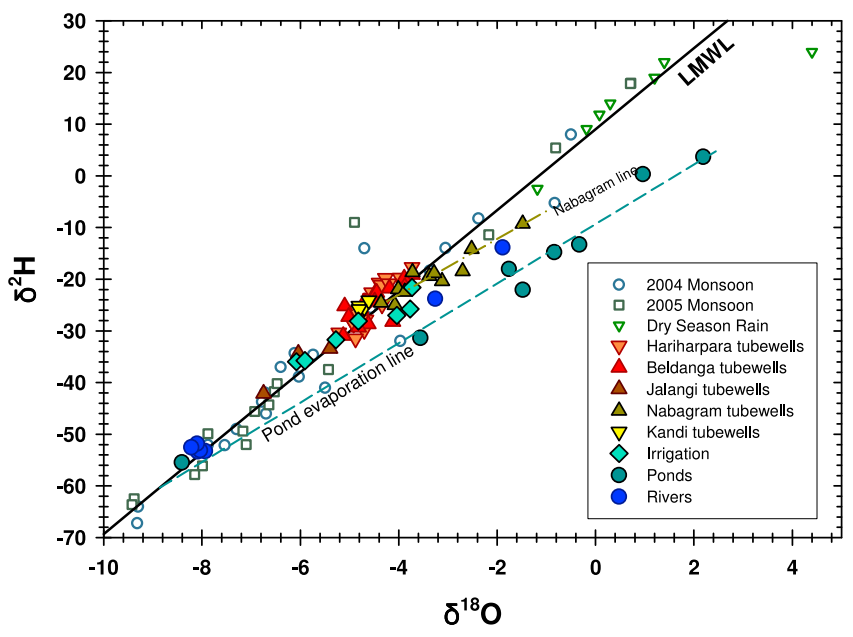

Figure 2. Stable oxygen and hydrogen isotope values in per mil (\%o) of waters from West Bengal, India. Monsoon and dry season precipitation are from Sengupta and Sarkar [2006] and Mukherjee et al. [2007]. A reduced major axis (RMA) regression fit to these data provides a local meteoric water line (LMWL) of $\delta^{2} \mathrm{H}=7.83 \delta^{18} \mathrm{O}+9.01$ with $\mathrm{r}=0.965$. This LMWL differs only slightly from recent estimates of the LMWL at Kolkata (e.g., $\delta^{2} \mathrm{H}=7.88 \delta^{18} \mathrm{O}+8.93$ [Sengupta and Sarkar, 2006]; $\delta^{2} \mathrm{H}=8.03 \delta^{18} \mathrm{O}+8.27$ [Kumar et al., 2010]). RMA was employed because it allows for regression when both variables $\left(\delta^{2} \mathrm{H}, \delta^{18} \mathrm{O}\right)$ exhibit similar analytical variations [Davis, 1986]. Also shown is the RMA fit for Nabagram groundwaters. 


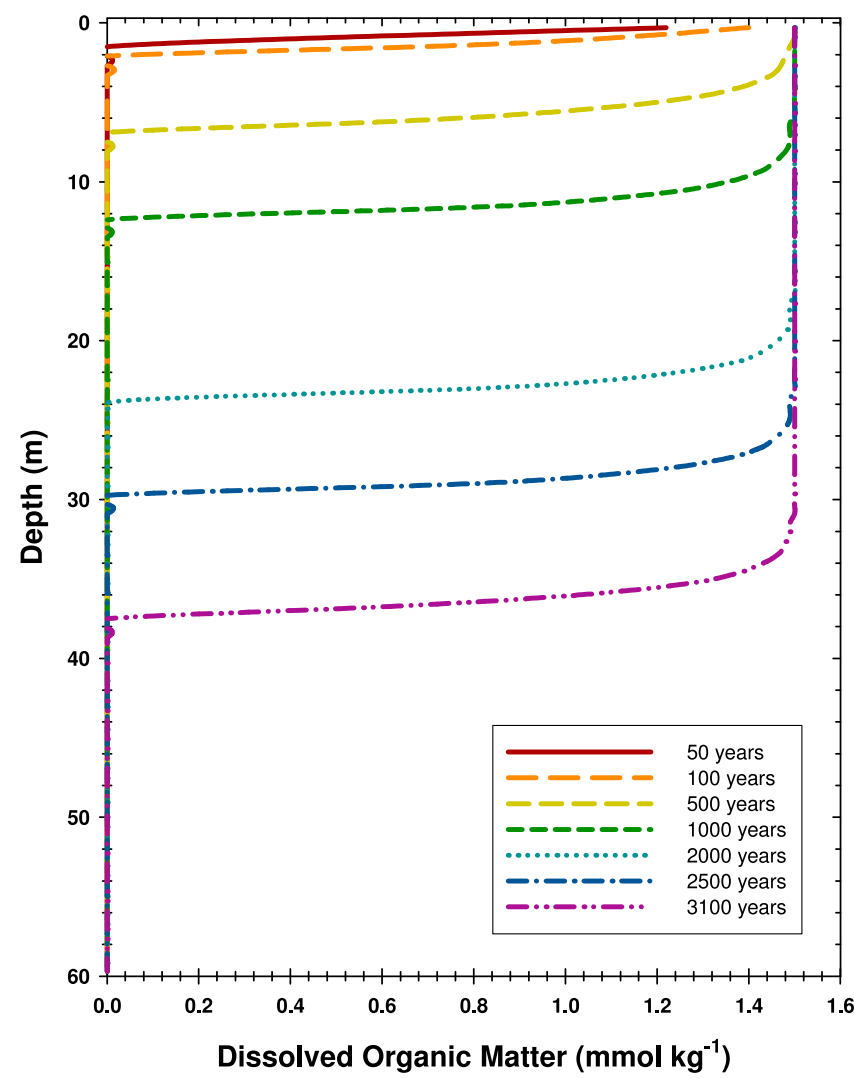

Figure 3. Results of 1-D advective-dispersive transport model for dissolved organic matter (DOM) originating in shallow, perennial ponds. The transport model is linked to the generalized, two-layer surface complexation model [Dzombak and Morel, 1990] to simulate organic matter adsorption/desorption in the system. The model assumes a uniform porosity of $30 \%$, an average, downward groundwater velocity of $0.6 \mathrm{~m} \mathrm{year}^{-1}$, and the pond water has a DOM concentration of $1.5 \mathrm{mmol} \mathrm{kg}-1$ (see auxiliary material).

McArthur et al., 2010]). Specifically, the model predicts that pond-derived DOM would travel less than $2 \mathrm{~m}$ into the underlying sediments in 50 years, and would require in excess of 2500 years to reach a depth of $30 \mathrm{~m}$ below the ground surface (Figure 3). Furthermore, the model demonstrates that downward transport of pond-derived DOM would require on the order of a millennium to reach the top of the As-affected aquifers (i.e., depths $>10 \mathrm{~m}$; Figure 3). Lower DOM concentrations (e.g., $0.5 \mathrm{mmol} \mathrm{kg}{ }^{-1}$ [Neumann et al., 2010]) serve only to increase transport times (Figure $\mathrm{S} 3$ of the auxiliary material). We note that because the model does not account for differences in permeability between the silty-clay layers at the surface and the underlying sand aquifers, the model actually under predicts DOM travel times. Nevertheless, the model results are broadly consistent with radiocarbon ages of dissolved inorganic and organic carbon (DIC, DOC) in groundwaters from neighboring Bangladesh that reveal relatively young DIC $\left(700{ }^{14} \mathrm{C}\right.$ years $)$ and much older DOC $\left(3000-5000{ }^{14} \mathrm{C}\right.$ years) at $\sim 30 \mathrm{~m}$ depth in the aquifer [Harvey et al., 2002]. The weak acid properties of DIC indicates that carbonic acid species are less surface reactive than DOC and consequently will be transported more conservatively with flowing groundwater than DOC. The radiocarbon age of DOC in the Bangladesh ground- waters are similar to those of wood fragments from the same depth [Goodbred and Kuehl, 1999; Harvey et al., 2002], supporting our contention of a local, aquifer source for the DOM.

\section{Conclusions}

[11] Arsenic concentrations in shallow groundwaters $(\sim 30 \mathrm{~m})$ from the Murshidabad district of West Bengal are among the highest measured in the Bengal Basin. Stable hydrogen and oxygen isotope analysis and reactive transport modeling indicates that the source of these groundwaters and the organic carbon that drives microbial respiration of Fe(III) and subsequent release of sorbed/co-precipitated As, cannot be ascribed to infiltration from constructed, perennial surface ponds. Specifically, $\delta^{2} \mathrm{H}$ and $\delta^{18} \mathrm{O}$ values of Murshidabad pond waters indicate that these ponds are recharged by summer monsoon precipitation and subsequently undergo extensive evaporation during the dry season. In contrast, the high As groundwaters have not experienced any detectable evaporation, plotting instead along the LMWL near where the annual, volume-weighted mean precipitation values for $\delta^{2} \mathrm{H}$ and $\delta^{18} \mathrm{O}$ would plot. The stable water isotope data demonstrate that the high As groundwaters are recharged by local precipitation without significant evaporation or mixing with evaporated pond waters. Reactive transport modeling indicates that transport of pond-derived DOM to depth in the underlying aquifer where As is mobilized would require thousands of years, thus far exceeding the estimated age ( $\sim 50$ years) of shallow, As-rich groundwaters.

[12] Acknowledgments. This work was supported in part by funds from Kansas State University to S. Datta, National Science Foundation (NSF) grant EAR-0805332 to K. Johannesson, and NSF grant EAR1014946 to K. Johannesson and S. Datta. We are grateful for the comments of the editor Paolo D'Odorico and two anonymous reviewers, which greatly improved the manuscript. Please direct any inquiries to the corresponding author Karen Johannesson.

[13] The Editor thanks the two anonymous reviewers for their assistance in evaluating this paper.

\section{References}

Clark, I., and P. Fritz (1997), Environmental Isotopes in Hydrogeology, 328 pp., Lewis, Boca Raton, Fla.

Davis, J. C. (1986), Statistics and Data Analysis in Geology, 646 pp., John Wiley, New York.

Dixit, S., and J. G. Hering (2003), Comparison of arsenic(V) and arsenic (III) sorption onto iron oxide minerals: Implications for arsenic mobility, Environ. Sci. Technol., 37, 4182-4189, doi:10.1021/es030309t.

Dzombak, D. A., and F. M. M. Morel (1990), Surface Complexation Modeling: Hydrous Ferric Oxide, 393 pp., John Wiley, New York.

Goodbred, S. L., Jr., and S. A. Kuehl (1999), Holocene and modern sediment budgets for the Ganges-Brahmaputra river system: Evidence for highstand dispersal to flood-plain, shelf, and deep-sea depocenters, Geology, 27, 559-562, doi:10.1130/0091-7613(1999)027<0559: HAMSBF $>2.3 . \mathrm{CO} ; 2$.

Haque, S., J. Ji, and K. H. Johannesson (2008), Evaluating mobilization and transport of arsenic in sediments and groundwaters of Aquia aquifer, Maryland, USA, J. Contam. Hydrol., 99, 68-84, doi:10.1016/j. jconhyd.2008.03.003.

Harvey, C. F., et al. (2002), Arsenic mobility and groundwater extraction in Bangladesh, Science, 298, 1602-1606, doi:10.1126/science.1076978.

Harvey, C. F., et al. (2006), Groundwater dynamics and arsenic contamination in Bangladesh, Chem. Geol., 228, 112-136, doi:10.1016/j.chemgeo. 2005.11.025.

Klump, S., R. Kipfer, O. A. Cirpka, C. F. Harvey, M. A. Brennwald, K. N. Ashfaque, A. B. M. Badruzzaman, S. J. Hug, and D. M. Imboden (2006), Groundwater dynamics and arsenic mobilization in Bangladesh using noble gases and tritium, Environ. Sci. Technol., 40, 243-250, doi:10.1021/es051284w. 
Kumar, R., S. P. Rai, U. Saravana Kumar, S. K. Verma, P. Garg, S. V. Vijaya Kumar, R. Jaiswal, B. K. Purendra, S. R. Kumar, and N. G. Pande (2010), Isotopic characteristics of Indian precipitation, Water Resour. Res., 46, W12548, doi:10.1029/2009WR008532.

McArthur, J. M., et al. (2004), Natural organic matter in sedimentary basins and its relation to arsenic in anoxic ground water: the example of West Bengal and its worldwide implications, Appl. Geochem., 19, 1255-1293, doi:10.1016/j.apgeochem.2004.02.001.

McArthur, J. M., D. M. Banerjee, S. Sengupta, P. Ravenscroft, S. Klump, A. Sarkar, B. Disch, and R. Kipfer (2010), Migration of As, and 3H/3He ages, in groundwater from West Bengal: Implications for monitoring, Water Res., 44, 4171-4185, doi:10.1016/j.watres.2010.05.010.

Mukherjee, A., A. E. Fryar, and H. D. Rowe (2007), Regional-scale stable isotope signatures of recharge and deep groundwater in the arsenic affected areas of West Bengal, India, J. Hydrol., 334, 151-161, doi:10.1016/j.jhydrol.2006.10.004.

Neal, A., J. Haug, R. A. Socki, T. Ocheltree, E. Petroske, K. H. Johannesson, R. Dhar, and S. Datta (2010), Understanding heterogeneity in sediment geochemistry in contrasting groundwater arsenic bearing environments in Murshidabad, West Bengal, India, Geol. Soc. Am. Abstr. Programs, 42(5), 503.

Neumann, R. B., K. N. Ashfaque, A. B. M. Badruzzaman, M. A. Ali, J. K. Shoemaker, and C. F. Havey (2010), Anthropogenic influences on groundwater arsenic concentrations in Bangladesh, Nat. Geosci., 3, 46-52, doi:10.1038/ngeo685.

Nickson, R. T., J. M. McArthur, P. Ravenscroft, W. G. Burgess, and K. M. Ahmed (2000), Mechanism of arsenic release to groundwater, Bangladesh and West Bengal, Appl. Geochem., 15, 403-413, doi:10.1016/S08832927(99)00086-4.

Ravenscroft, P., H. Brammer, and K. Richards (2009), Arsenic Pollution: A Global Synthesis, 588 pp., Wiley-Blackwell, Chichester, U. K., doi:10.1002/9781444308785.

Sengupta, S., and A. Sarkar (2006), Stable isotope evidence of dual (Arabian Sea and Bay of Bengal) vapour sources in monsoonal precipitation of north India, Earth Planet. Sci. Lett., 250, 511-521, doi:10.1016/j. eps1.2006.08.011.

Sengupta, S., J. M. McArthur, A. Sarkar, M. J. Leng, P. Ravencroft, R. J. Howarth, and D. M. Banerjee (2008), Do ponds cause arsenic-pollution of groundwater in the Bengal Basin? An answer from West Bengal, Environ. Sci. Technol., 42, 5156-5164, doi:10.1021/es702988m.

Smith, A. H., E. O. Lingas, and M. Rahman (2000), Contamination of drinking water by arsenic in Bangladesh: A public health emergency, Bull. World Health Organ., 78, 1093-1103.

Stute, M., et al. (2007), Hydrological control of As concentrations in Bangladesh groundwater, Water Resour. Res., 43, W09417, doi:10.1029/2005WR004499.

van Geen, A., et al. (2003), Spatial variability of arsenic in 6000 tube wells in a $25 \mathrm{~km}^{2}$ area, Water Resour. Res., 39(5), 1140, doi:10.1029/ 2002 WR001617.

Yu, W. H., C. M. Harvey, and C. F. Harvey (2003), Arsenic in groundwater in Bangladesh: a geostatistical and epidemiological framework for evaluating health effects, and potential remedies, Water Resour. Res., 39(6), 1146, doi:10.1029/2002WR001327.

Zheng, Y., M. Stute, A. van Geen, I. Gavrieli, R. Dhar, H. J. Simpson, P. Schlosser, and K. M. Ahmed (2004), redox control of arsenic mobilization in Bangladesh groundwater, Appl. Geochem., 19, 201-214, doi:10.1016/j.apgeochem.2003.09.007.

S. Datta and A. W. Neal, Department of Geology, Kansas State University, Manhattan, KS 66506, USA.

K. H. Johannesson, T. J. Mohajerin, and B. E. Rosenheim, Department of Earth and Environmental Sciences, Tulane University, New Orleans, LA 70118, USA.

T. Ocheltree, Division of Biology, Kansas State University, Manhattan, KS 66506, USA.

C. D. White, Department of Petroleum Engineering, Louisiana State University, Baton Rouge, LA 70803, USA. 